\title{
К ВОПРОСУ О СОЦИАЛИЗАЦИИ МОЛОДЕЖИ В УСЛОВИЯХ СРЕДНЕГО ПРОФЕССИОНАЛЬНОГО ОБРАЗОВАНИЯ
}

\author{
Д.А. Фёдорова \\ Московский гуманитарный университет
}

\begin{abstract}
Аннотация: B статье автор анализирует особенности студенческого коллектива, его воспитательный потенциал, возможности его формирования в условиях среднего профессионального образования.

Ключевые слова: студенческий коллектив, студенческое самоуправление, среднее профессиональное образование, формирование коллектива, воспитательная система колледжа
\end{abstract}

\section{ON THE ISSUE OF SOCIALIZATION OF YOUTH IN THE CONDITIONS OF SECONDARY VOCATIONAL EDUCATION}

\author{
D.A. Fedorova \\ Moscow University for the Humanities
}

\begin{abstract}
: in the article, the author analyzes the features of the student collective, its educational potential and the possibilities of its formation in the conditions of secondary vocational education.

Keywords: student collective, student self-government, secondary vocational education, collective formation, educational system of the college
\end{abstract}

В современном динамичном обществе, для благополучного и высоко социального функционирования, необходимо быть развитой личностью, обладающей такими качествами, как инициативность, идейность, креативность и целеустремленность. Эти и многие другие социально значимые качества закладываются в студенческие годы. В активной социальной среде студент, как минимум, проецирует нестандартные решения задач, находит возможности сотрудничества с преподавателями, со студентами из других групп или даже других вузов, а также перенимает опыт от старшекурсников и участвует в различных творческих активностях.

Данная проблема широко и много лет обсуждается учеными. Известно, что в студенческой группе происходят динамичные процессы структурирования, формирования и изменения межличностных взаимоотношений, распределения групповых ролей и выдвижения лидеров. Эти процессы в значительной степени воздействуют на личность студента, на его поведение, на успешность учебно-профессиональной деятельности и социализацию. Поэтому так важно понимать и учитывать особенности студенческого коллектива при организации образовательной деятельности, а также при подготовке педагогических кадров.

Более подробно необходимо остановиться на самом термине «коллектив». 
Коллектив (от лат. colligere) - собирать, объединять. Понятие «коллектив» употребляется в двух значениях:

1) организация, группа людей (на предприятии, в учебном заведении, в какой-либо организации и т.д.);

2) высокий уровень развития группы, характеризующийся целеустремлённостью, сплочённостью, духовным единством (Словарь практического психолога, 1998).

Психолого-педагогическая литература выделяет, в основном, постоянные (учебная группа, отделение) и временные (научное общество, команда) коллективы, каждый из которых обладает набором специфических функций от простого регулирования процессами до саморазвития и совершенствования каждого субъекта.

Сегодня среднее профессиональное образование является одним из наиболее востребованных видов образования. Его цель - подготовка высококвалифицированных специалистов, сочетающих достаточно широкую теоретическую подготовку с практико-ориентированными умениями, удовлетворяющими текущие потребности рынка труда.

У современных выпускников СПО высокая ответственность перед обществом - для востребованности на рынке труда, они должны обладать не только некоторыми профессиональными видами деятельности, знаниями, умениями, но и высокими нравственными качествами, и психологическим опытом работы с людьми.

Взаимоотношения студентов на протяжении всего периода обучения в организации СПО, развиваются и совершенствуются. Так, с поступлением, например, в колледж, отмечается уменьшение коллективных связей и взаимоотношений между обучающимися. Это объясняется новизной коллектива и новой для студента деятельностью. Как раз на этом этапе социализации личности обучающегося и необходимо подключить воспитательное воздействие коллектива, в рамках которого приобретаются первые навыки самостоятельной организаторской работы, реализуется творческий потенциал (Иванова, 2016).

В системе СПО, в частности в колледжах, основой коллектива обучающихся является учебная группа. Для запуска эффективного функционирования пока еще формально созданных коллективов педагогическим работникам приходится проводить большую организаторскую работу. Как правило, начинается она с изучения состава группы, индивидуальных особенностей студентов. Первичным источником информации об обучающихся может служить, например, анкета и медицинская справка. Формируя и изучая личные дела, педагог имеет возможность получить первое представление о составе группы, о тех или иных особенностях каждого студента, а также наметить возможные приоритетные задачи с пометками «активные» или «риски». При этом необходимо помнить, 
что формируя план работы с группой педагогу важно заметить эмоциональную составляющую и первое впечатление ребят о колледже, выяснить которое поможет уже первая беседа с группой.

На протяжении всего периода обучения взаимоотношения между сверстниками легко диагностировать через организацию внеучебной деятельности. В неофициальной обстановке обучающийся может проявлять черты характера, которые не заметны на занятиях. Еще одна важная составляющая в формировании студенческого коллектива это правильное распределение общественных поручений. Необходимо убедить студентов в том, что, выполняя даже небольшое поручение группы, они вносят свой вклад в улучшение учебного процесса.

Постепенно в коллективе группы непосредственные эмоциональные связи и взаимоотношения начинают подкрепляться нравственной оценкой поведения каждого из студентов. Ребята все глубже осознают те или иные качества личности, а сходство в интересах и делах является важным фактором сближения и возникновения новых познавательных интересов. И этому также способствует правильно организованная воспитательная работа, о которой пойдет речь далее.

Современная педагогика рассматривает несколько моделей формирования коллектива студенческой группы, каждая из которых фиксирует особые стадии в этом движении. Наиболее известные А.С. Макаренко, Б.Т. Лихачев, В.А. Сухомлинский, и ряд современных исследователей - Т.Е. Конникова, В.Р. Попов, Д. Трофимов и другие.

Развернутая концепция формирования коллектива принадлежит А.В. Петровскому (Петровский, 1976). Он рассматривает группу как состоящую из трех слоев. В первом слое реализуются непосредственные контакты между студентами, основанные на эмоциональной приемлемости или неприемлемости. Во втором слое эти отношения отражаются в характере совместной деятельности. В третьем слое, названном ядром группы, развиваются отношения, основанные на принятии всеми членами группы единых целей групповой деятельности.

Формирование коллектива - процесс перманентный. Однако, прежде чем предлагать определенные задачи группе на какой-либо период, например на учебный год, надо наиболее четко распознать его «место» на пути к коллективу. Ведь в студенческой группе осуществляется динамичное структурирование, формирование и изменение межличностных взаимоотношений, распределение групповых ролей, выставление лидеров и т.п. Все эти процессы оказывают особое влияние на успешность функционирования и профессионального становления. Исходя из вышесказанного, особую роль в работе со студенческой группой приобретает необходимость грамотной организации взаимодействия студентов, сотрудничества в студенческом коллективе, в формировании которого на первом месте - роль педагогического работника. 
Воспитательная система колледжа представляет собой комплекс взаимосвязанных блоков-компонентов: цели, деятельность, обеспечивающая их реализацию, субъекты деятельности, ее организующие и в ней участвующие, отношения, внутреннее управление, обеспечивающее интеграцию всех компонентов системы в единое целое.

В виду того, что основной целью воспитательной работы является развитие личности обучающегося, отметим основные задачи воспитания в колледже:

- формирование у обучающихся гражданской ответственности и правового самосознания;

- духовности и культуры;

- инициативности и самостоятельности;

- толерантности;

- способности к активной адаптации на рынке труда.

Безусловно, поставленные задачи направлены на то, чтобы в колледже господствовали благоприятная атмосфера, искренняя вера в возможности каждого и транслирование защищенности со стороны взрослого, как следствие, - наличие постоянной развивающей среды, обеспечивающей поддержание духовной раскрепощенности воспитанников. Все эти задачи реализуются в группах.

Разнообразные мероприятия и направления деятельности - гражданскопатриотическое воспитание, формирование здорового образа жизни, спортивная, культурно-массовая работа и т.д., направлены на воспитание всесторонне развитой личности, развитие творческого потенциала обучающихся, их научных, художественных, технических, спортивных, организационно-коммуникативных навыков. Особое внимание уделяется формированию ценностных ориентаций обучающихся в процессе самодеятельного творчества. Так в социальнопсихологических процессах в коллективе молодых людей, в условиях творческой деятельности у обучающихся формируются ценностные ориентации. При этом творческая направленность деятельности в группе выступает одновременно и как средство удовлетворения художественных потребностей, и как одна из форм общения, и как путь к самоутверждению, самовыражению личности.

Важным средством воспитательного воздействия и формирования коллектива является самоуправление. К тому же, оно может принимать разнообразные очертания и особенности по мере развития коллектива. Студенческое самоуправление - это явление, безусловно, сложное, и наряду с другими такими же явлениями, присущими данному возрасту или данной среде, требует планомерной работы педагогического и ученического сообщества.

В группе с подлинным самоуправлением процесс воспитания личности содействует воспитанию воли, самосознания, чувства долга, возбуждает стремление совершенствовать свои качества, осуществлять работу по самовоспитанию в общественно полезной деятельности. Заметим, что смысл 
студенческого самоуправления выражается не в простом управлении одних другими, а в сложном овладении социально-значимых умений, направленных, как это ни парадоксально, на умение управлять собой. В ряд ключевых задач самоуправления можно поставить осваивание студентами на более высоких уровнях общих компетенций и их непосредственную тренировку, а также защиту прав и решение самых существенных вопросов учебного процесса.

Конечно, в ситуации самоуправления необходимо соблюдать процессуальный баланс между вмешательством педагогов в групповые отношения и необходимостью, так или иначе, диагностировать состояние всех взаимодействий. Воспитанию инициативных, сильных личностей, способных умело управлять собственной жизнью, способствует правильно организованное самоуправление, при котором оказывается поддержка студентам, которые нуждаются в укреплении собственной позиции.

Подводя итог вышесказанному, отметим, что формирование коллектива в организациях СПО, является неотъемлемой частью целостного образовательного процесса, который в условиях взаимодействия всех его участников строится на грамотной организации. Хотелось бы особо подчеркнуть некую индивидуальность и специфичность студенческого коллектива, имеющего огромный потенциал для изучения с одной лишь сложностью, четко сформулированной современным исследователем Д. Трофимовым: «Мир студенческих корпораций одновременно и замкнут, и открыт. Этот мир не открывается сразу, его трудно понять, глядя на него со стороны, так как большая часть его жизни происходит внутри (Трофимов, 2014).

\section{СПИСОК ЛИТЕРАТУРЫ}

Беляев В.И. (2000) Педагогика А.С. Макаренко: традиции и новаторство. Москва: МНЭПУ. 224 с.

Иванова Е.Е. (2016) Социально-педагогические основы организации воспитательной работы в ВУЗе В сборнике: Высшее образование для XXI века. Доклады и материалы ХІІІ Международной научной конференции. М.: МосГУ. С. 7-13.

Конникова Т.Е. (1957) Организация коллектива учащихся в школе. М.: АПН РСФСР. 400 c.

Лихачев Б.Т. (2010) Педагогика. Курс лекций. М.: Владос. 646 с.

Новикова Л.И. (2010) Педагогика воспитания: Избранные педагогические труды Педагогика воспитания: избранные педагогические труды. М.: ПЕР СЭ, 2010. C. 13.

Петровский А.В. (1976) Общая психология: Учебник для студентов педагогических институтов 2-е изд. перераб. и доп. М.: Просвещение. 479 с.

Попов В.Р. (2009) Студенческое самоуправление: опыт сравнительного историко-социологического анализа //Вопросы образования. № 2. 
Словарь практического психолога (1998). М.: АСТ, Харвест. С. Ю. Головин.

Сухомлинский В.А. (1979) Избранные педагогические сочинения. М.: Педагогика.

Трофимов Д. (2014) Студенческая корпорация и ее принципы. [Электронный peсурс]. Сноб. URL: https://snob.ru/profile/28418/blog/78327?v=1459770065 (дата обращения: 28.09.2020).

Фёдорова Дарья Александровна - магистрант 2 курса кафедры педагогики и психологии высшей школы Московского гуманитарного университета. Научный руководитель: кандидат психологических наук, доцент Е.Е. Иванова. Адрес: 111395, Россия, г. Москва, ул. Юности, д. 5. Тел.: +7 90133917 65. Эл. адрес: dashenka. fedorova@gmail.com

Fedorova Darya Aleksandrovna - 2nd year master's student, department of pedagogy and psychology of the higher school of the Moscow humanitarian university. Scientific Director: Candidate of Psychological Sciences, Associate Professor E.E. Ivanova. Address: 5 Yunosti str., Moscow, 111395, Russia. Tel.: +7 90133917 65. email address: dashenka.fedorova@gmail.com 